\title{
ESTIMATES OF THE DIFFERENCE BETWEEN TWO WEIGHTED INTEGRAL MEANS VIA WEIGHTED MONTGOMERY IDENTITY
}

\author{
A. Aglić Aljinović, J. PeČArić AND I. Perić
}

Abstract. Some new generalizations of estimates of difference between two weighted integral means are given, by using Euler-type identities and weighted Montgomery identity

Mathematics subject classification (2000): 26D10, 26D15, 26D20.

Key words and phrases: Bernoulli polynomials, Montgomery identity, weighted integral means.

\section{REFERENCES}

[1] M. AbRamowitz AND I. A. STEGUn (EDS), Handbook of mathematical functions with formulae, graphs and mathematical tables, National Bureau of Standars, Applied Math. Series 55, 4th printing, Washington 1965.

[2] A. Aglić AlJinović, M. Matić AND J. PEČARIĆ, Improvements of some Ostrowski type inequalities, (submitted).

[3] G. A. AnAstassiou, Univariate Ostrowski inequalities, Monatshefte für Mathematik 135, 175-189 (2002).

[4] N. S. Barnett, P. Cerone, S. S. Dragomir AND A. M. FinK, Comparing two integral means for absolutely continuous mappings whose derivatives are in $L_{\infty}[a, b]$ and applications, Computers and Math. With Appl. 44 (2002), 241-251.

[5] P. CERONE, On a identity for the Chebychev functional and some ramifications, RGMIA Res. Rep. Coll., Vol 3, Issue 1, No 4 (2002).

[6] P. Cerone And S. S. DRAGOMIR, Diferences between means with bounds from a Riemann-Stieltjes integral, RGMIA Res. Rep. Coll., Vol 4, No. 2, (2001).

[7] P. CERONE AND S. S. DRAGOMIR, On some inequalities arising from Montgomery identity, RGMIA. Res. Rep. Coll. Vol 3, No 2 (2000).

[8] LJ. Dedić, M. MATIĆ AND J. PEČARIĆ, On generalizations of Ostrowski inequality via some Euler-type identities. Math. Inequal. \& Appl., 3 (3) (2000), 337-353.

[9] A. M. FINK, Bounds of the deviation of a function from its averages, Czechoslovak Math. J., 42 (117) (1992), 289-310.

[10] J. PEČARIĆ, I. PERIĆ, A. VUKELIĆ, Estimates of the difference between two integral means via Euler-type identities, Math. Inequal. \& Appl. 7 (3) (2004), 365-378. 